\title{
Grazing impact of natural populations of ciliates and dinoflagellates in a river-influenced continental shelf
}

\author{
Cristian A. Vargas*, Rodrigo A. Martínez \\ Aquatic Research Unit, Environmental Sciences Center EULA Chile, Universidad de Concepción, PO Box 160-C, \\ Concepción, Chile
}

\begin{abstract}
The abundance and biomass of ciliates and dinoflagellates in a nearshore area affected by freshwater runoff and coastal upwelling events were assessed during 7 campaigns distributed over winter and spring months between 2006 and 2008 in the Itata river plume and off Coliumo Bay in Central Chile $\left(\sim 36^{\circ} \mathrm{S}\right)$. Grazing rates were also established for both aloricate ciliate and naked dinoflagellate populations using data on instantaneous food vacuole content via the uptake of fluorescently labelled algae (FLA). Both dinoflagellates and ciliates were more abundant in the less saline waters of the river plume. The dominant micrograzers on FLA were the dinoflagellates Gyrodinium spp. and Gymnodinium spp. and the ciliates Strombidium spp. Ingestion by naked dinoflagellates ranged from 0.06 to 0.14 prey $\mathrm{d}^{-1}$, whereas aloricate ciliates ingested between 20 and 35 prey $\mathrm{d}^{-1}$. Maximum carbon ingestion of naked dinoflagellates occurred during spring, whereas it peaked both in winter and in spring in aloricate ciliates. The highest grazing impact of ciliates on nanoplankton $\left(\sim 99 \%\right.$ of primary production $\left.\mathrm{d}^{-1}\right)$ occurred during winter within the river plume. The higher abundance of small potential prey, as well as the resulting higher grazing impact of microzooplankton during winter in the river plume area, suggest an adequate environment for protozoan growth.
\end{abstract}

KEY WORDS: Naked dinoflagellates · Aloricate ciliates · Grazing impact · Microbial food web · River plume

Resale or republication not permitted without written consent of the publisher

\section{INTRODUCTION}

It has long been recognized that the microbial community consisting of bacteria, nano- and microzooplankton plays an important role in coastal food webs (Pomeroy 1974). The microzooplankton fraction constitutes an important group of heterotrophic and mixotrophic organisms in the size range of 20 to $200 \mu \mathrm{m}$, which includes many protists (ciliates, dinoflagellates, and foraminiferans) as well as small metazoans (copepod nauplii, and some invertebrate larvae) (Calbet 2008). Because of their often dominant role within the microzooplankton, ciliates and dinoflagellates have recently received much attention, which has mainly focused on their role as primary consumers of pico- and nano-sized producers (Vargas et al. 2007), as well as their biogeochemical role as nutrient regenerators
(Calbet 2008). In fact, in nearshore waters, the microheterotrophic pathway mediated by ciliates and dinoflagellates has been proven to constitute an important link between small cell and bacterial carbon and upper trophic levels (Vargas \& González 2004, Vargas et al. 2007, 2008).

Aloricate ciliates have been reported to graze between 10 and $80 \%$ of primary production (PP) in various marine environments (Rassoulzadegan et al. 1988), and evidence for the importance of obligate heterotrophic dinoflagellates as grazers of phytoplankton in marine ecosystems is also accumulating (Lessard \& Swift 1985, Sherr \& Sherr 2007, Vargas et al. 2007). Although it has been assumed that the microzooplankton community is usually dominated by ciliates, nonpigmented dinoflagellates, including both armoured forms and naked gymnodinoid species, frequently 
compose $>50 \%$ of microzooplankton biomass, and often occur in high abundance during diatom blooms in nearshore waters (Sherr \& Sherr 2007).

The abundance and feeding behaviour of microprotozoans have been reported from polar to temperate waters, but little is known about their significance in food webs of estuarine and river-influenced continental shelf waters. High and variable input of freshwater in river-influenced continental shelves creates surface salinity gradients associated with high spatial variability in inorganic and organic nutrient concentrations as well as in phytoplankton biomass and production (Dagg et al. 2004). Some studies have indicated that toxic dinoflagellate blooms often coincide with enhanced rainfall, freshwater runoff, and water column stratification (Hallegraeff et al. 1995, Weise et al. 2002). In continental shelf areas where the flux of DOM from freshwater runoff may be significant and where bacterial biomass and production are relatively high (Dagg et al. 2004), it is especially likely for microzooplankton to play a major role in channelling that production to higher trophic levels (Vargas et al. 2007).

In the present study, we did a quantitative evaluation of the contribution of ciliates and dinoflagellates to microzooplankton biomass and the effects of freshwater runoff on microzooplankton abundances on a seasonal basis in a river-influenced coastal upwelling area. Due to their small size and the difficulty in separating predators from prey by conventional size-fractionation methods, grazing rates of ciliates and dinoflagellates for nearshore areas in the Humboldt current system (HCS) have not been previously reported. Here, we determined in situ grazing rates of both ciliate and dinoflagellate populations of the HCS using instantaneous food vacuole content to evaluate their grazing impact on nanoflagellate communities.

\section{MATERIALS AND METHODS}

Study area. Our study area is located on the continental shelf off Concepción, Central Chile $\left(36^{\circ} \mathrm{S}\right)$. The area is characterised as one of the widest parts of the continental shelf along the Chilean coastal margin, as well as by the influence of freshwater discharges from the Itata and Bío-Bío rivers, with mean water outflows of 286 and $1699 \mathrm{~m}^{3} \mathrm{~s}^{-1}$, respectively. The runoff from these rivers supplies significant amounts of silicate, nitrate, and phosphate as well as trace metals to the coastal ocean (Sánchez et al. 2008). The area is also characterised by the occurrence of seasonal upwelling events during the austral spring-summer (Vargas et al. 2007). Due to these events, upwelling-driven phytoplankton blooms, typically dominated by long-chain forming diatoms, occur during those seasons (Vargas et al. 2007), resulting in one of the highest PP rates $(\sim 4$ to $20 \mathrm{~g} \mathrm{C} \mathrm{m}^{-2} \mathrm{~d}^{-1}$ ) reported for the world's oceans (Montero et al. 2007). Two stations with maximum depths of $40 \mathrm{~m}$ were established nearshore off the coast of central Chile. Stn RV was located in the plume region of the Itata River and Stn UW was $\sim 20 \mathrm{~km}$ southeast off Coliumo Bay (Fig. 1).

Seawater sampling and hydrography. Samples were taken on seven 2 d cruises aboard the LC 'Kay Kay' (Universidad de Concepción) during a spring-summer and a winter period as part of the Ommix Project (Influence of Omnivory and Mixotrophy in Food Web Dynamics). Field sampling was conducted twice in December 2006 (spring), June 2007 (winter), and December 2007 (spring), and once in August 2008 (winter). At each station, temperature, salinity, oxygen, and fluorescence profiles were recorded from near the bottom to the surface using a CTD (SeaBird SBE-19 plus) equipped with an oxygen sensor (YSI-calibrated Beckman) and a fluorometer (Wetstar). Water samples (1 1) for the determination of nanoplankton and microplankton abundance and biomass were collected at discrete depths $(1,5,10,25$, and $35 \mathrm{~m})$ with a rosette system equipped with 12 Niskin bottles. Nanoplankton samples were preserved in glutaraldehyde $(6.0 \% \mathrm{w} / \mathrm{v}$ in $0.2 \mu \mathrm{m}$ prefiltered seawater). Microplankton samples were preserved in an alkaline solution of $1 \%$ Lugol (Levinsen \& Nielsen 2002). Additional samples

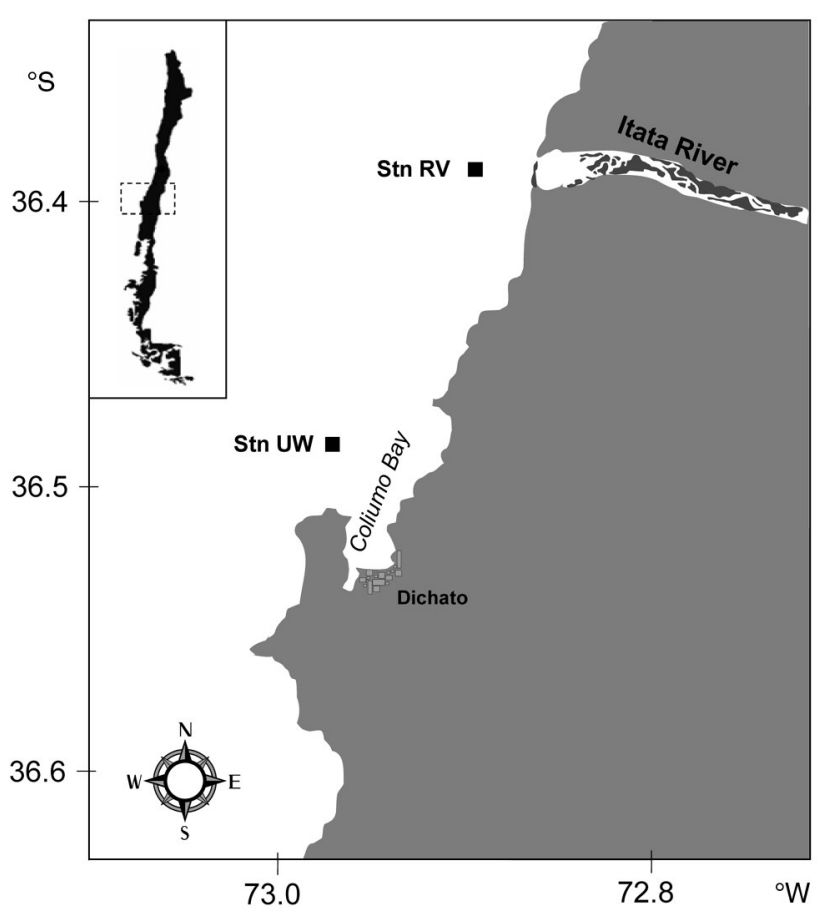

Fig. 1. Study area and locations of the sampling stations in the Itata river plume area (Stn RV) and in the upwelling site off Coliumo Bay, Chile (Stn UW) 
were also collected from the surface, at the fluorescence maximum depth, and at $1 \%$ PAR (photosynthetically active radiation) depth for nutrient concentration and grazing experiments (5 l) (see 'Estimates of daily in situ ingestion rates'). Samples for nutrient analysis, including nitrate $\left(\mathrm{NO}_{3}{ }^{-}\right)$, nitrite $\left(\mathrm{NO}_{2}{ }^{-}\right)$, phosphate $\left(\mathrm{PO}_{4}{ }^{-3}\right)$, and silicate $\left(\mathrm{Si}(\mathrm{OH})_{4}\right)$ were GF/F filtered onboard and frozen $\left(-20^{\circ} \mathrm{C}\right)$ until analysis in the laboratory. $\mathrm{NO}_{3}{ }^{-}$and $\mathrm{PO}_{4}{ }^{-3}$ were determined spectrophotometrically following Strickland \& Parsons (1968). $\mathrm{NO}_{2}^{-}$ was analyzed using an automated nutrient analyzer (ALPKEM, Flow Solution IV) following the protocol of Strickland \& Parsons (1968). River flow data was obtained from the National Water Directorate (www.dga.cl). The Brunt-Väisälä frequency was estimated as an index of water column stratification over the study period. PAR information was obtained from the Meteorological Stn HOBO located off Coliumo (COPAS Center, Universidad de Concepción).

Ciliate and dinoflagellate abundance and biomass. Ciliates and dinoflagellates from seawater samples (50 and $100 \mathrm{ml}$ ) were counted and measured after $24 \mathrm{~h}$ of settling, using an inverted microscope with phase optics (Olympus IX-51) at $200 \times$ magnification. Dinoflagellates, aloricate ciliates, and tintinnids were measured and identified down to genus level. Some individuals were identified to species level based on cell size and shape, body contour, and shape and position of dinoflagellate plates (for dinoflagellates), as well as body shape, lorica and collar appearance (for ciliates). Individuals were enumerated by scanning the entire chamber at 100 to $400 \times$ magnification. Cell sizes were measured with an ocular micrometer and converted into cell volumes assuming conical shapes with length to diameter ratios of 1.25 for ciliates $<50 \mu \mathrm{m}$ and 2 for ciliates $>50 \mu \mathrm{m}$ (Tiselius 1989). Carbon to plasma

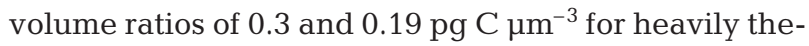
cate and thecate dinoflagellates forms, respectively (E. J. Lessard unpubl. Gifford \& Caron 2000), and $0.148 \mathrm{pg}$ C $\mu \mathrm{m}^{-3}$ for ciliates (Ohman \& Snyder 1991), were applied. For the enumeration of phototrophic (PNF) and heterotrophic nanoflagellates (HNF) as potential prey for ciliates and dinoflagellates, subsamples were filtered on a $0.8 \mu \mathrm{m}$ polycarbonate membrane filter and stained with proflavine $(0.033 \% \mathrm{w} / \mathrm{v}$ in distilled water $)$ following Haas (1982). Nanoflagellates were counted with an inverted microscope (Olympus IX-51) equipped with UV model (U-MWU2; band width pass 330 to $385 \mathrm{~nm}$ ) and fluorescein isothiocyanate (FITC) model (U-MWB2; band width pass 450 to $480 \mathrm{~nm}$ ) filter sets.

Since several of our environmental measurements were non-independent (e.g. river flow and salinity), a principal component analysis (PCA) was used to separate environmental variability into orthogonal vectors, which are computed as linear combinations of the environmental variables originally measured. We used the principal components that explained the largest percentage of the total variance to represent environmental variability in the study region, and to control for potential differences in regimes of environmental variability between sampling seasons. A correlation analysis was then conducted to explore the connection between these principal components and microzooplankton abundance and composition.

Estimates of daily in situ ingestion rates. The specific grazing activity of dinoflagellates and ciliates on algae were assessed by short-term ( $4 \mathrm{~h}$ ) fluorescently labelled algae (FLA) uptake (Rublee \& Gallegos 1989). For the preparation of the FLA stock, we used the haptophyte Isochrysis galbana cultured in filtered seawater enriched with $\mathrm{f} / 2$ medium at $12^{\circ} \mathrm{C}$, with a $12: 12 \mathrm{~h}$ light:dark cycle in the hatchery of the Universidad de Concepción in Dichato (Fig. 1). Algal cultures at the exponential phase of growth were used for all the experiments. The FLA was 4 to $6 \mu \mathrm{m}$ in diameter, which resembles the size of the nanoflagellates in the natural community in coastal waters off Concepción (Anabalón et al. 2007). Labelling of the algae followed the procedure of Sherr et al. (1987), except that centrifugation was done at $800 \times g$. Algae were resuspended in $10 \mathrm{ml}$ of phosphate-buffered saline $(0.05 \mathrm{M}$ $\mathrm{Na}_{2} \mathrm{HPO}_{4}$ in $0.85 \% \mathrm{NaCl}$ adjusted to $\mathrm{pH} 9$ ) and incubated for 2 to $3 \mathrm{~h}$ at $54^{\circ} \mathrm{C}$ with $2 \mathrm{mg}$ DTAF (5-[4,6dichlorotriazinyl]aminofluorescein). Incubation was followed by several washes with phosphate-buffered saline as suggested by Rublee \& Gallegos (1989).

For ingestion rate estimations, 2501 borosilicate bottles were filled in triplicate with seawater from the fluorescence maximum depth (see Table 1). The seawater samples were previously gently reverse filtered through a $250 \mu \mathrm{m}$ filter to remove large grazers. FLA preparation and uptake experiments followed procedures developed for the analysis of FLA uptake by pelagic protozoans (Sherr \& Sherr 1993). Feeding rates were determined using a modification of the food vacuole content (FVC) method of Li et al. (2001), with digestion of FLA rather than live prey. FLA concentration was based on the analysis of natural nanoflagellate abundance in the study area and literature values. Typical abundances of nanoflagellates in the nearshore area off Concepcion ( $<10 \mathrm{n}$ mile from the coast) on a seasonal basis range between $5 \times 10^{1}$ to $3 \times 10^{3}$ cells $\mathrm{ml}^{-1}$ (Vargas et al. 2007). In addition, the literature suggests that the optimum concentration for feeding experiments is $>500$ to $1000 \mathrm{FLA} \mathrm{ml}^{-1}$, which normally corresponds to a fraction of the total phytoplankton standing stock in mesotrophic or eutrophic waters (Sherr \& Sherr 1993). Thus, a FLA aliquot was added at final concentrations of $1 \times 10^{3}$ cells ml $^{-1}$, which repre- 
sented $\sim 50 \%$ of the highest abundance of nanoflagellates in the study area (Vargas et al. 2007). Small subsamples were taken at time zero $\left(t_{0}\right)$ to determine the exact concentration of FLA added to the samples. Bottles were incubated at in situ temperature for $4 \mathrm{~h}$. At the end of the incubations, $50 \mathrm{ml}$ subsamples were taken from all bottles, fixed with glutaraldehyde (final concentration of $2 \%$; Christaki et al. 1999), and stained with a combination of $1200 \mu \mathrm{l}$ of DAPI (final concentration of $4 \mu \mathrm{g} \mathrm{ml}^{-1}$ ) and $600 \mu \mathrm{l}$ of proflavine (final concentration of $0.033 \%$; Haas 1982). Double staining with proflavine and DAPI was employed to aid the visualization of protistan cells and to stain both the cytoplasm and the nucleus. Whole stained samples were filtered on $0.8 \mu \mathrm{m}$ Nuclepore filters and stored at $-20^{\circ} \mathrm{C}$ until analysis. Analysis was performed at a magnification of $1000 \times$ using the Olympus IX-51 inverted microscope with UV excitation to observe DTAF and blue light excitation to observe proflavine and chlorophyll auto-fluorescence. Under UV excitation, Isochrysis chloroplasts fluoresced reddish orange, whereas differentiation between dinokaryons in dinoflagellates and ingested haptophyte nuclei was based on size, brightness, and location of the DAPI signal. The presence of ingested FLA was recorded from the analysis of the whole filter. These data were used to calculate the mean number of FLA in food vacuoles per dinoflagellate or ciliate for each replicate on each sampling occasion.

For the first set of experiments in December 2006, digestion rate $(k)$ was estimated for dinoflagellates feeding on FLA. With this purpose, a seawater sample was cleared of natural nanoflagellate prey by reverse filtration through $23 \mu \mathrm{m}$ nitex mesh and stored in $250 \mathrm{l}$ borosilicate bottles (Rublee \& Gallegos 1989). After allowing the natural microplankton community to recover from handling shock (60 $\mathrm{min})$, an aliquot of FLA was gently stirred into the samples. After addition of FLA, the natural microplankton assemblage was allowed to feed for $4 \mathrm{~h}$ at in situ temperature. Subsamples $(50 \mathrm{ml})$ were then taken every $1 \mathrm{~h}$, and a similar procedure of fixation, staining, and analysis was done. Specific digestion rate constants $(k)$ were calculated by linear regression analysis (Li et al. 2001) of the disappearance of FLA from food vacuoles. When the number of FLA ingested was not enough for $k$ estimations, we used the mean digestion rate of $0.004 \mathrm{~h}^{-1}$ that was reported for the naked dinoflagellate Gyrodinium galatheanum feeding on the cryptophyte Storeatula major at $15^{\circ} \mathrm{C}$ ( $\mathrm{Li}$ et al. 2001). Nevertheless, we are aware that the species G. galatheanum is a primarily autotrophic species as opposed to obligate heterotrophs, which probably characterise most of the dinoflagellates found in our study. A digestion rate of $0.924 \%$ cell content $\mathrm{min}^{-1}$ was used for the ciliate
Strombidium sp. This digestion rate corresponds to the mean half food vacuole passage time of $75 \mathrm{~min}$ as determined by Dolan \& Šimek (1997) for Strombidium sulcatum grazing on a series of different prey (i.e. microspheres, Synechococcus and Isochrysis galbana). Ingestion rates (prey d ${ }^{-1}$ ) were obtained by multiplying the FVC value (FLA predator ${ }^{-1}$ ) by $k$. Then, clearance rate was estimated by dividing the ingestion rate by the FLA concentration. Carbon ingestion rate was calculated by multiplying the ingestion rate, assuming a constant carbon content per cell of $13.6 \mathrm{pg}$ C for I. galbana (Hansen 1993). Carbon ingestion by naked dinoflagellates and aloricate ciliates was calculated as the sum of the integrated abundance (0 to $20 \mathrm{~m}$ depth) of each species/genus, multiplied by the individual ingestion rate (estimated from FLA uptake). Since ingestion rates were estimated for the most abundant ciliates and dinoflagellates (typically comprising $\sim 70$ to $80 \%$ of the total biomass of every group), these ingestion rates were assumed to represent the total grazing impact of these protozoan populations.

\section{RESULTS}

\section{Physical/chemical environment}

Surface temperature and salinity ranged from 11 to $15^{\circ} \mathrm{C}$ and 32.5 to 34.5 over the study period. CTD profiles indicated the presence of a well-defined seasonal thermocline located between 3 and $10 \mathrm{~m}$ depth at both sampling stations during spring campaigns (Ommix I, II, V and VI). The physical/chemical differences between sampling sites were clearly reflected in differences in salinity and inorganic nutrient availability (Fig. 2, Table 1). Salinity profiles at Stn RV showed the influence of the freshwater runoff from Itata River on the hydrographic characteristics of the surface water column, with a shallow layer of less-saline water located in the upper $5 \mathrm{~m}$ (except in spring 2007) (Fig. 2c,d), when river flow was $<20 \mathrm{~m}^{3} \mathrm{~s}^{-1}$ (Fig. 2e). The water column at Stn UW was always relatively mixed in terms of salinity, although lower salinity values were also observed in the upper $10 \mathrm{~m}$ during the winter of 2008 (Ommix VII, Fig. 2d), when maximum river runoff was observed (Fig. 2e). On a seasonal basis, mean nutrient concentration in surface waters showed higher values for all nutrients during winter campaigns (Ommix III, IV, and VII). Concentrations of $\mathrm{Si}(\mathrm{OH})_{4}$ were comparatively higher in the surface layer in the river plume at Stn RV (Table 1), indicating that terrigenous input by river discharge strongly influenced the coastal environment. However, $\mathrm{NO}_{3}{ }^{-}$and $\mathrm{PO}_{4}{ }^{-3}$ concentrations were generally higher at Stn UW, both at the surface and at the fluorescence maximum 
depth. The fluorescence maximum was deeper in the water column at Stn RV during winter (Table 1), which is probably associated with the effect of sediment loading from the Itata River. PAR showed seasonal distribution, with the highest values being observed during spring and low values being noted in winter (Fig. 2e).

\section{Microzooplankton abundance and biomass}

Most dinoflagellates and ciliates were identified only to genus level. Dinoflagellate abundances ranged from 0 to 16 and 0 to 190 cells $\mathrm{ml}^{-1}$ for armoured and naked forms, respectively (Figs. 3 \& 4). Tintinnid abundances
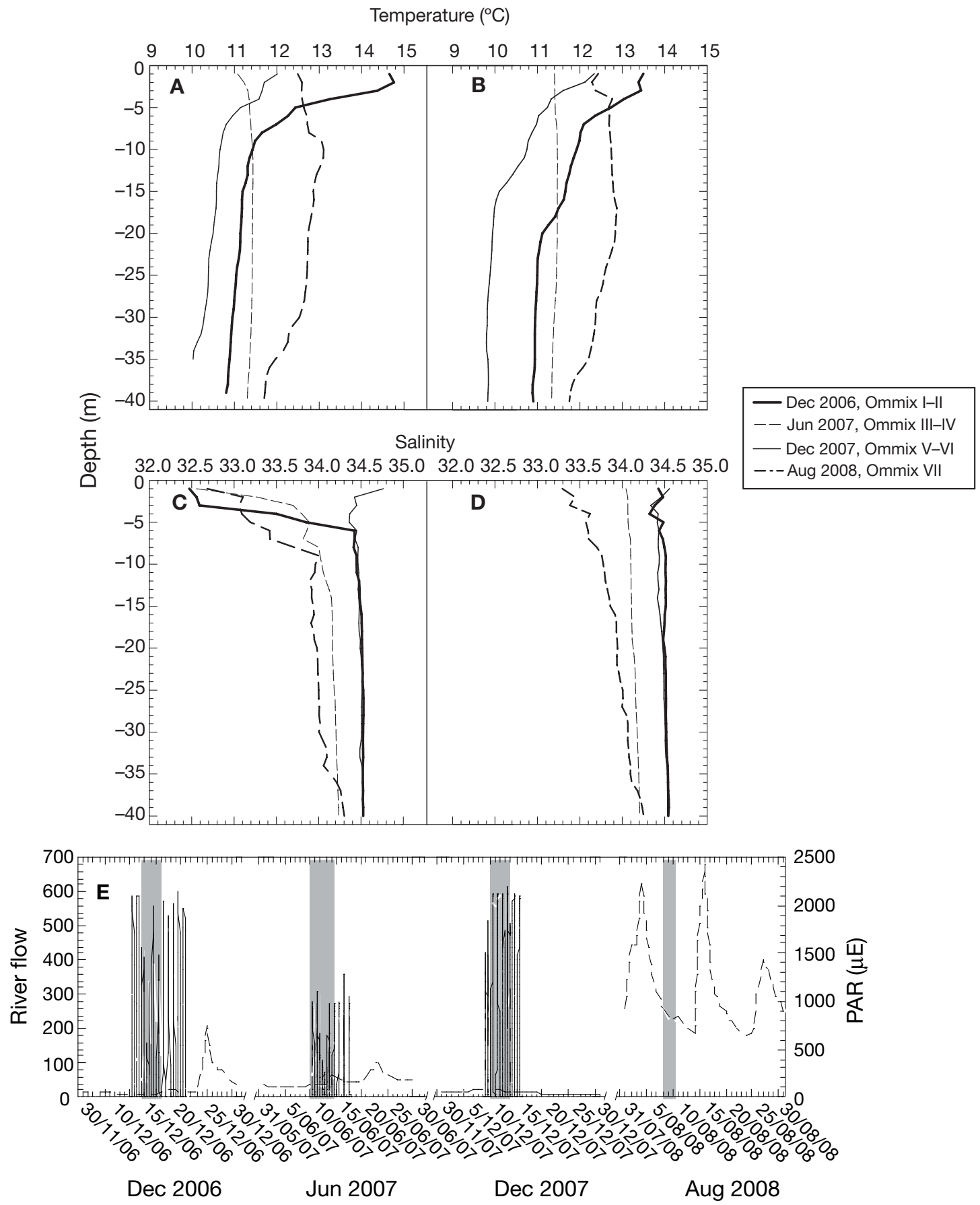

Fig. 2. Temperature and salinity profiles for Stn RV $(A, C)$ and Stn UW (B,D) averaged for each season/Ommix campain. (E) Mean daily river flow $\left(\mathrm{m}^{3} \mathrm{~s}^{-1}\right.$ ) (dashed line) and hourly PAR data (solid thin line) for December 2006, June 2007, December 2007, and August 2008. Grey shaded rectangles in (E) denote the period in which the seasonal cruises took place. PAR data was not available for August 2008. Dates given as dd/mm/yy 
Table 1. Mean concentration $(\mu \mathrm{M})$ of $\mathrm{NO}_{3}{ }^{-}, \mathrm{NO}_{2}{ }^{-}, \mathrm{PO}_{4}{ }^{-3}, \mathrm{Si}(\mathrm{OH})_{4}$, and $\mathrm{Si}: \mathrm{N}$ ratio at the surface and at the fluorescence maximum (fluor. max.) depth (m) during each Ommix campaign conducted at both sampling stations

\begin{tabular}{|c|c|c|c|c|c|c|c|c|}
\hline \multirow[b]{2}{*}{ Ommix: } & \multicolumn{4}{|c|}{ Stn RV (River plume) } & \multicolumn{4}{|c|}{ - Stn UW (off Coliumo Bay) } \\
\hline & $\begin{array}{c}\text { I-II } \\
\text { Dec } 2006\end{array}$ & $\begin{array}{c}\text { III-IV } \\
\text { Jun } 2007\end{array}$ & $\begin{array}{c}\text { V-VI } \\
\text { Dec } 2007\end{array}$ & $\begin{array}{c}\text { VII } \\
\text { Aug } 2008\end{array}$ & $\begin{array}{c}\text { I-II } \\
\text { Dec } 2006\end{array}$ & $\begin{array}{c}\text { III-IV } \\
\text { Jun } 2007\end{array}$ & $\begin{array}{c}\text { V-VI } \\
\text { Dec } 2007\end{array}$ & $\begin{array}{c}\text { VII } \\
\text { Aug } 2008\end{array}$ \\
\hline \multicolumn{9}{|l|}{ Surface $(1 \mathrm{~m})$} \\
\hline $\mathrm{NO}_{3}^{-}$ & 1.33 & 14.10 & 18.88 & 11.44 & 2.34 & 18.90 & 12.24 & 12.46 \\
\hline $\mathrm{NO}_{2}^{-}$ & 0.09 & 0.39 & 0.34 & 0.41 & 0.07 & 0.49 & 0.24 & 0.45 \\
\hline $\mathrm{PO}_{4}^{-3}$ & 0.40 & 1.70 & 1.61 & 0.98 & 0.75 & 1.93 & 1.08 & 1.02 \\
\hline $\mathrm{Si}(\mathrm{OH})_{4}$ & 6.34 & 16.50 & 17.21 & 28.32 & 1.63 & 13.05 & 5.73 & 21.41 \\
\hline Si:N ratio & 4.48 & 1.14 & 0.90 & 2.39 & 0.68 & 0.67 & 0.46 & 1.66 \\
\hline Fluor. max. depth & 10 & 8 & 10 & 8 & 10 & 5 & 10 & 5 \\
\hline $\mathrm{NO}_{3}^{-}$ & 17.94 & 12.35 & 16.16 & 9.80 & 11.02 & 16.90 & 7.63 & 11.36 \\
\hline $\mathrm{NO}_{2}^{-}$ & 0.23 & 0.46 & 0.25 & 0.47 & 0.13 & 0.43 & 0.30 & 0.65 \\
\hline $\mathrm{PO}_{4}^{-3}$ & 2.35 & 1.85 & 1.70 & 0.99 & 0.88 & 1.84 & 1.64 & 1.03 \\
\hline $\mathrm{Si}(\mathrm{OH})_{4}$ & 9.75 & 9.00 & 7.45 & 4.30 & 0.62 & 9.55 & 8.45 & 6.97 \\
\hline Si:N ratio & 0.54 & 0.70 & 0.45 & 0.42 & 0.06 & 0.55 & 0.47 & 0.58 \\
\hline
\end{tabular}

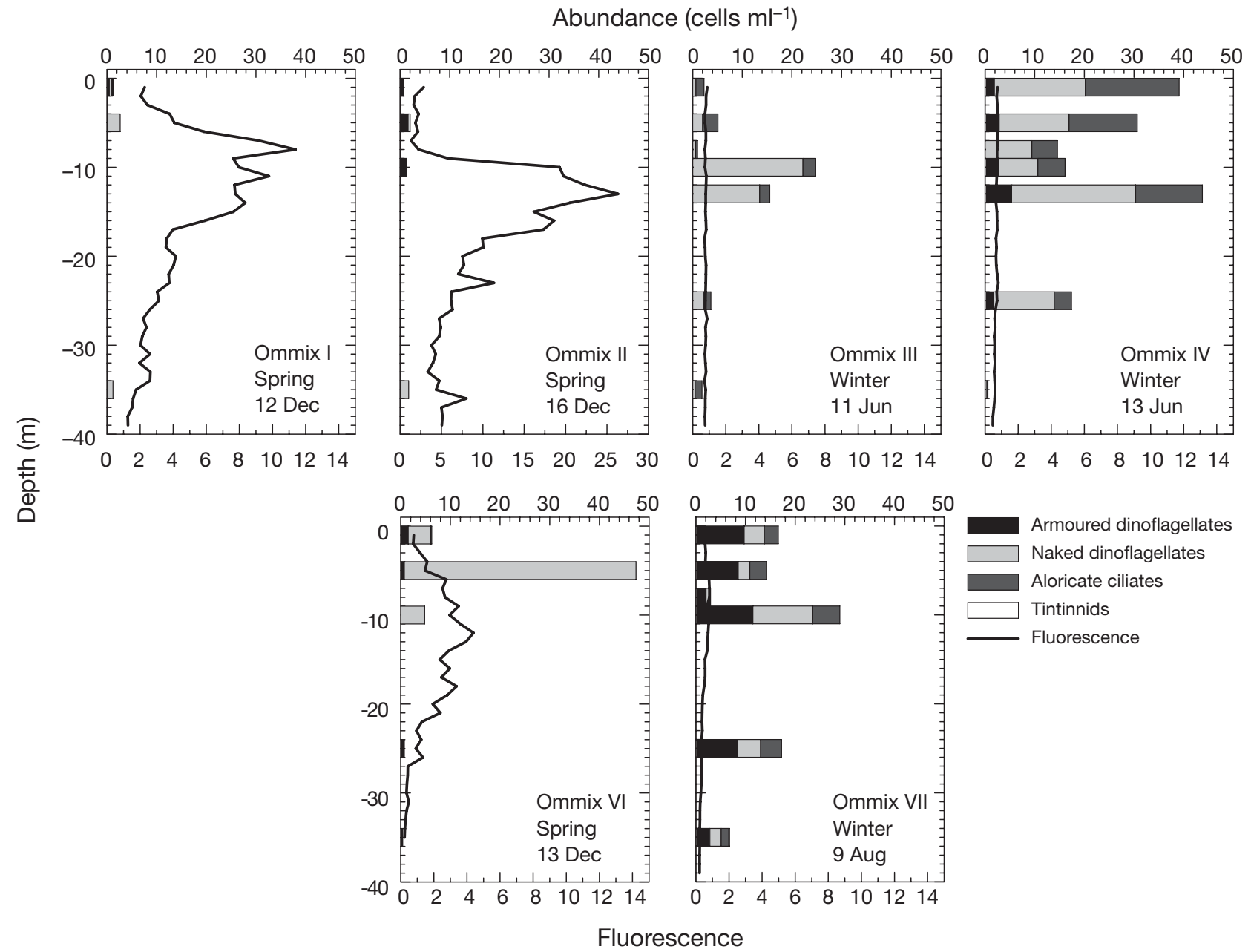

Fig. 3. Vertical distribution of armoured and naked dinoflagellates, aloricate ciliates, and tintinnids in the river plume area (Stn RV) for each Ommix campaign. The fluorescence profile is also included for each date. Missing data during Ommix V was due to bad weather conditions 

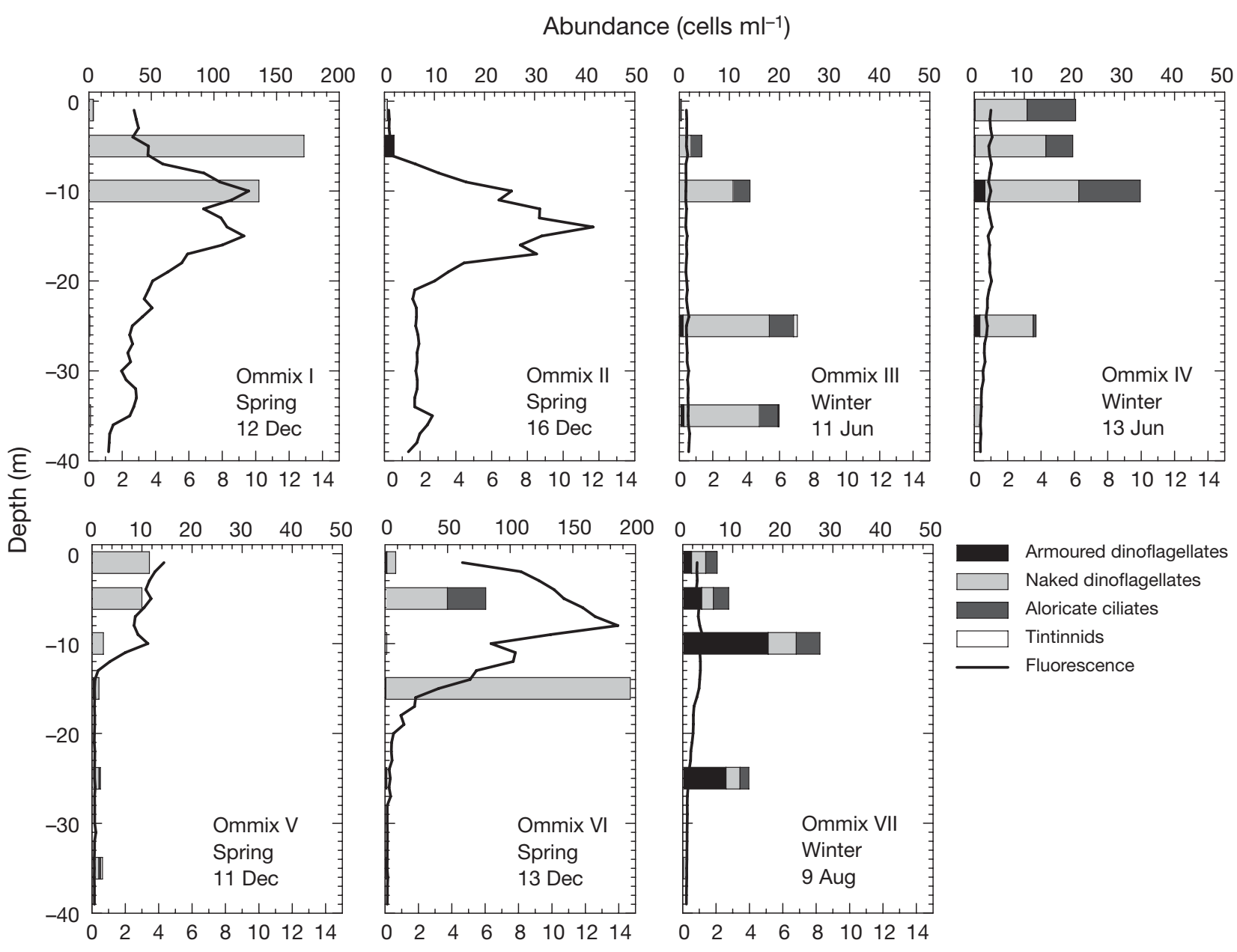

Fluorescence

Fig. 4. Vertical distribution of armoured and naked dinoflagellates, aloricate ciliates, and tintinnids off Coliumo Bay (Stn UW) for each Ommix campaign. The fluorescence profile is also included for each date. Note the different $x$-axes scales for Ommix I and VI due to a large peak in the abundance of naked dinoflagellates

were always $<2$ cells $\mathrm{ml}^{-1}$, whereas aloricate ciliates

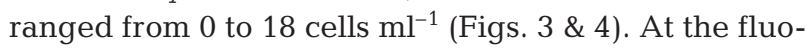
rescence maximum depth where FLA experiments were conducted, the most well represented dinoflagellate taxa were armoured species of the genera Protoperidinium, and naked dinoflagellates of the genera Gymnodinium and Gyrodinium (Table 2). The highest abundance of armoured dinoflagellates occurred during winter campaigns, whereas naked individuals were present throughout the study period, with a peak at the fluorescence maximum during spring 2006 at Stn UW. For the ciliate community, aloricate species of the genera Strombidium and Strobilidium were the dominant taxa, with maximum abundances during winter 2007 and 2008 at Stn RV. Tintinnid ciliates were represented only occasionally by species of the genera Helicostomella, Salpingella, and Udella (Table 2).
The highest dinoflagellate abundance occurred in the subsurface layers, between 5 and $15 \mathrm{~m}$ depth, especially at Stn RV (Fig. 3). At both stations, aloricate ciliates and naked dinoflagellates were regularly encountered above or within the fluorescence maximum layer, except for a large bloom of the heterotrophic dinoflagellates Gyrodinium spp. (size range: 10 to $28 \mu \mathrm{m}, \sim 200$ cells $\mathrm{ml}^{-1}$ ) at $15 \mathrm{~m}$ during spring 2007 (Ommix VI) at Stn UW (Fig. 4). Aloricate ciliates, when present, were encountered throughout the water column, with a maximum abundance in winter (2007-2008) in the upper $10 \mathrm{~m}$ of both sampling sites (Figs. $3 \& 4$ ).

The PCA of environmental data produced a first principal component (PC1) that explained $27.5 \%$ of the total variability (Table $3 a$ ). An inspection of the weights assigned by PC1 to the original variables 
Table 2. Mean abundance (cells $\mathrm{l}^{-1}$ ) of numerically dominant ciliates and dinoflagellates at the fluorescence maximum depth where fluorescently labelled algae (FLA) experiments were conducted at both sampling stations for each campaign

\begin{tabular}{|c|c|c|c|c|c|c|c|c|}
\hline \multirow[b]{2}{*}{ Ommix: } & \multicolumn{4}{|c|}{$-\mathrm{Stn} R V$} & \multicolumn{4}{|c|}{ - Stn UW } \\
\hline & $\begin{array}{c}\text { I-II } \\
\text { Dec } 2006\end{array}$ & $\begin{array}{c}\text { III-IV } \\
\text { Jun } 2007\end{array}$ & $\begin{array}{c}\text { V-VI } \\
\text { Dec } 2007\end{array}$ & $\begin{array}{c}\text { VII } \\
\text { Aug } 2008\end{array}$ & $\begin{array}{c}\text { I-II } \\
\text { Dec } 2006\end{array}$ & $\begin{array}{c}\text { III-IV } \\
\text { Jun } 2007\end{array}$ & $\begin{array}{c}\text { V-VI } \\
\text { Dec } 2007\end{array}$ & $\begin{array}{c}\text { VII } \\
\text { Aug } 2008\end{array}$ \\
\hline Mean fluorescence max. & 10 & 8 & 10 & 8 & 10 & 5 & 10 & 5 \\
\hline \multicolumn{9}{|l|}{ Dinoflagellates } \\
\hline Protoperidinium leonis & 661 & 0 & 0 & 0 & 0 & 126 & 0 & 0 \\
\hline Protoperidinium spp. $25-50 \mu \mathrm{m}$ & 0 & 851 & 0 & 766 & 0 & 128 & 0 & 304 \\
\hline Dinophysis acuminata & 0 & 0 & 25 & 639 & 0 & 28 & 0 & 0 \\
\hline Gymnodinium spp. 8-20 $\mu \mathrm{m}$ & 0 & 3821 & 4338 & 1150 & 0 & 4559 & 745 & 456 \\
\hline Gyrodinium spp. $10-28 \mu \mathrm{m}$ & 13 & 357 & 482 & 255 & 67934 & 635 & 572 & 0 \\
\hline Katodinium spp. $18-20 \mu \mathrm{m}$ & 0 & 0 & 0 & 861 & 0 & 22 & 0 & 304 \\
\hline Not identified athecate & 42 & 0 & 0 & 0 & 13 & 43 & 0 & 0 \\
\hline Total armoured & 661 & 851 & 25 & 1405 & 0 & 282 & 0 & 304 \\
\hline Total naked & 55 & 4178 & 4820 & 2266 & 67947 & 5260 & 1317 & 760 \\
\hline \multicolumn{9}{|l|}{ Ciliates } \\
\hline Helicostomella spp. & 5 & 0 & 23 & 23 & 12 & 0 & 0 & 0 \\
\hline Udella spp. & 0 & 0 & 12 & 287 & 0 & 0 & 0 & 0 \\
\hline Salpingella spp. & 5 & 0 & 0 & 23 & 5 & 0 & 0 & 0 \\
\hline Strombidium capitatum & 0 & 567 & 40 & 1435 & 0 & 888 & 0 & 1179 \\
\hline Strombidium compressum & 0 & 8 & 0 & 0 & 0 & 11 & 0 & 2063 \\
\hline Strombidium spp. & 29 & 1474 & 24 & 1722 & 16 & 12 & 30658 & 1474 \\
\hline Strobilidium spp. & 0 & 74 & 24 & 0 & 0 & 11 & 0 & 0 \\
\hline Laboea spp. & 0 & 210 & 0 & 0 & 0 & 13 & 0 & 0 \\
\hline Total loricate & 10 & 0 & 35 & 333 & 17 & 0 & 0 & 0 \\
\hline Total aloricate & 29 & 2332 & 88 & 3158 & 16 & 936 & 30658 & 4717 \\
\hline
\end{tabular}

indicated that this could be interpreted as 'nutrient conditions' (Table 3a), with the heaviest weights corresponding to $\mathrm{NO}_{2}^{-}$and $\mathrm{PO}_{4}{ }^{-3}$ concentrations, as well as to the Si:N and N:P ratios. The second principal component (PC2) explained an additional $22.4 \%$ of the total variability (Table $3 a$ ). The signs of the heaviest weights assigned by PC2 to the original variables (negative for temperature, positive for salinity, nitrate, silicate and N:P ratio; Table 3a) suggest that this component represents 'upwelling variability' (i.e. cold and saline nutrient-rich upwelled waters). Finally, a third principal component (PC3) explained $18.5 \%$ of the total variability which, unlike the other 2 components, assigned a heavy weight to river flow (Table 3a). Weights of similar magnitude and sign as river flow were assigned to silicate and temperature, whereas salinity and fluorescence were weighted with the opposite sign (Table 3a). Hence, we interpreted PC3 as representing variability that corresponds to 'river flow dynamics'. Spearman correlations computed by season between each principal component and microzooplankton abundance (Table $3 \mathrm{~b}$ ) showed that during spring, both tintinnid and aloricate ciliates were positively and significantly correlated with PC1 and PC2 (i.e. nutrient conditions and upwelling variability). Tintinnids were also positively correlated with
PC3 (river flow dynamics) in spring. Positive correlations between tintinnid abundance and all 3 principal components persisted in the wintertime (Table $3 \mathrm{~b})$. However, only those with PC2 and PC3 were significant. Finally, the winter abundance of armoured dinoflagellates was positively correlated with PC1 (nutrient conditions) and negatively correlated with PC3 (river flow dynamics) (Table 3b).

The integrated biomass of ciliates and dinoflagellates in the upper $20 \mathrm{~m}$ ranged from 10 to $\sim 800 \mathrm{mg} \mathrm{C}$ $\mathrm{m}^{-2}$ (Fig. 5). Insignificant differences between stations were observed $(t$-test; $\mathrm{p}>0.01)$, except in spring (16 Dec 2006), when maximum biomass supported by armoured dinoflagellates was observed (Fig. 5b). This large biomass on 16 December 2006 was caused mostly by the occurrence of some cells of a large armoured dinoflagellate, Protoperidinium leonis (Table 2). This high biomass of armoured dinoflagellates coincided with the period of maximum water column stratification at the river plume area (Fig. 5a). The highest contributions of ciliates to the integrated biomass occurred during the winter campaigns (11 and 13 June 2007, and 9 August 2008), when aloricate ciliates contributed $\sim 50 \%$ to the total biomass. Low abundance of PNF was observed at times of maximum armoured dinoflagellate and ciliate biomass at Stn UW (Fig. 5c). 
Table 3. (a) Principal component analysis (PCA) performed on environmental data collected at both sampling locations. Columns show the weights assigned to originally measured variables. Only the components that explained $>8 \%$ of the total variance are reported. Assigned weights $>0.2$ are marked in bold. (b) Spearman correlation analysis (SPC) between reported principal component and microzooplankton groups. Significant correlations $(p<0.01)$ are marked in bold

\begin{tabular}{|c|c|c|c|c|}
\hline \multirow{2}{*}{\multicolumn{2}{|c|}{$\begin{array}{l}\text { (a) Physical/chemical } \\
\text { variable }\end{array}$}} & \multicolumn{3}{|c|}{ Principal component } \\
\hline & & PC1 & PC2 & PC3 \\
\hline \multicolumn{2}{|c|}{ Temperature $\left({ }^{\circ} \mathrm{C}\right)$} & -0.060 & -0.434 & -0.316 \\
\hline \multicolumn{2}{|l|}{ Salinity } & 0.003 & 0.289 & 0.480 \\
\hline \multicolumn{2}{|l|}{ Fluorescence } & 0.062 & 0.021 & 0.384 \\
\hline \multicolumn{2}{|l|}{$\mathrm{NO}_{3}{ }^{-}(\mu \mathrm{M})$} & 0.129 & 0.565 & -0.200 \\
\hline \multicolumn{2}{|l|}{$\mathrm{NO}_{2}^{-}(\mu \mathrm{M})$} & -0.545 & 0.115 & -0.013 \\
\hline \multicolumn{2}{|l|}{$\mathrm{PO}_{4}^{-3}(\mu \mathrm{M})$} & -0.544 & 0.185 & -0.021 \\
\hline \multicolumn{2}{|l|}{$\mathrm{Si}(\mathrm{OH})_{4}$} & -0.144 & 0.436 & -0.370 \\
\hline \multicolumn{2}{|l|}{ Si:N ratio } & -0.528 & -0.048 & -0.012 \\
\hline \multicolumn{2}{|l|}{$\mathrm{N}: \mathrm{P}$ ratio } & 0.276 & 0.397 & -0.162 \\
\hline \multirow{2}{*}{\multicolumn{2}{|c|}{$\begin{array}{l}\text { River flow } \\
\% \text { total variance }\end{array}$}} & 0.092 & -0.108 & -0.564 \\
\hline & & 27.5 & 22.4 & 18.5 \\
\hline \multirow{2}{*}{$\begin{array}{l}\text { (b) Principal } \\
\text { component }\end{array}$} & \multicolumn{2}{|c|}{ Ciliates } & \multirow{2}{*}{\multicolumn{2}{|c|}{$\begin{array}{l}\text { Dinoflagellates } \\
\text { Armoured Naked }\end{array}$}} \\
\hline & Tintinnids & Aloricates & & \\
\hline \multicolumn{5}{|l|}{ Spring } \\
\hline PC 1 & 0.406 & 0.378 & -0.081 & 0.097 \\
\hline PC 2 & 0.465 & 0.345 & 0.056 & -0.158 \\
\hline PC 3 & 0.346 & 0.225 & -0.019 & 0.221 \\
\hline \multicolumn{5}{|l|}{ Winter } \\
\hline PC 1 & 0.244 & 0.053 & 0.505 & 0.070 \\
\hline PC 2 & 0.417 & -0.288 & -0.289 & -0.232 \\
\hline PC 3 & 0.451 & 0.019 & -0.575 & 0.238 \\
\hline
\end{tabular}

\section{Ingestion rates of aloricate ciliates and naked dinoflagellates}

Cells of Isochrysis galbana stained uniformly and brightly within $2 \mathrm{~h}$ after DTAF addition. No background staining was observed in the microscopic preparations, and I. galbana when present, were easily detected within food vacuoles of heterotrophic Gymnodinium and Gyrodinium. Furthermore, the combination of DAPI and proflavine fluorochromes in sample preparation gave a better definition of predators, food vacuole shapes, and contents. The estimation of $k$ was only possible during the first set of experiments in winter 2006 (Ommix I), and a mean value of $0.0036 \mathrm{~h}^{-1}$ was obtained for an obligate heterotrophic species of Gymnodinium. Consequently, and considering the similarity with the value reported by Li et al. (2001) at $15^{\circ} \mathrm{C}$ for Gyrodinium galatheanum, we used an average value of $0.004 \mathrm{~h}^{-1}$ in our feeding rate estimations. It was not possible to estimate $k$ for ciliates such as Strombidium spp. and Strobilidium spp. Therefore, we used the mean $k$ value reported by Dolan \& Šimek
(1997) for Strombidium sulcatum fed with I. galbana. Uptake of FLA made with I. galbana occurred at both stations, with the FVC ranging from 1.2 to 2.5 prey dinoflagellate $^{-1}$ and from 2 to 3.5 prey ciliate $^{-1}$ (Table 4).

Gyrodinium spp. were estimated to ingest an average of 0.06 to 0.14 prey $\mathrm{d}^{-1}$, whereas Gymnodinium spp. ingestion ranged from 0.07 to 0.12 prey $\mathrm{d}^{-1}$ (Table 4). In both dinoflagellate genera, maximum ingestion rates were reached during spring (Ommix V and VI). The ingestion rate of aloricate ciliates Strombidium spp. was higher than those of the naked dinoflagellates, reaching values of $\sim 20$ to 35 prey $\mathrm{d}^{-1}$ (Table 4). Correspondingly, dinoflagellates and ciliates were estimated to clear an average of 2.5 to 5.8 and 0.8 to $1.5 \mu \mathrm{l} \mathrm{pred.} .^{-1} \mathrm{~h}^{-1}$, respectively (Table 5). Ingestion rate was not correlated with either nutrient concentration or $\mathrm{N}: \mathrm{P}$ and $\mathrm{Si}: \mathrm{N}$ ratios (data not shown).

Estimates of the potential carbon ingestion by naked dinoflagellates and aloricate ciliates feeding on nanoflagellate populations in both sampling sites are given in Fig. 6. Carbon ingestion was integrated for an average euphotic layer of $20 \mathrm{~m}$. Our results showed that

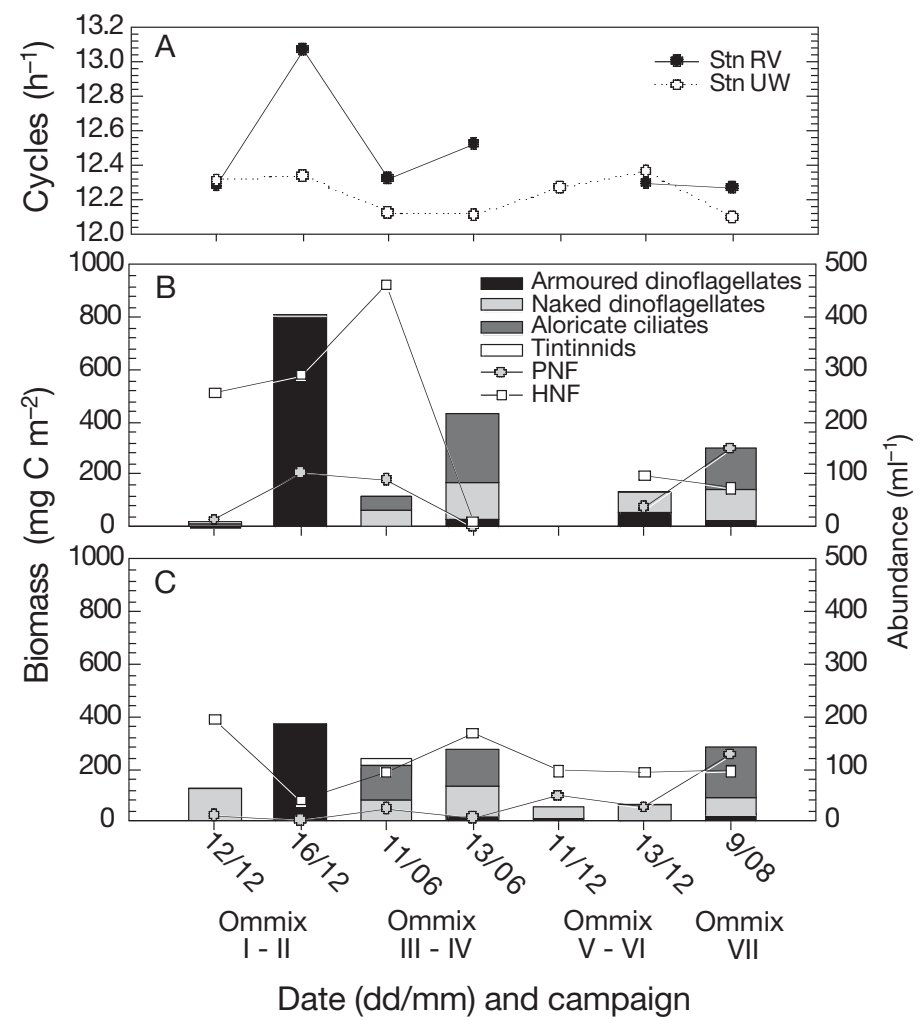

Fig. 5. (A) Brunt-Vaisälä frequency estimated for each sampling campaign in Stns RV and UW. $(B, C)$ Integrated abundance of ciliates and dinoflagellates in the upper $20 \mathrm{~m} \mathrm{(mg} \mathrm{C}$ $\mathrm{m}^{-2}$ ), and abundance of phototrophic (PNF) and heterotrophic (HNF) nanoflagellates (cells $\mathrm{ml}^{-1}$ ) during each Ommix campaign at (B) the river plume area (Stn RV), and (C) off Coliumo Bay (Stn UW) 
Table 4. Food vacuole contents (FVC) and ingestion rates of dinoflagellates and ciliates from both stations over the campaigns conducted in the present study

\begin{tabular}{|c|c|c|c|c|c|c|}
\hline Date & Campaign & Stn & Genera & $\begin{array}{l}\text { Temp } \\
\left({ }^{\circ} \mathrm{C}\right)\end{array}$ & $\begin{array}{c}\text { FVC } \\
\left(\text { prey vacuole }^{-1} \text { ) }\right.\end{array}$ & $\begin{array}{l}\text { Ingestion rate } \\
\quad\left(\text { prey d }^{-1}\right)\end{array}$ \\
\hline \multicolumn{7}{|c|}{ Dinoflagellates } \\
\hline 12 Dec 2006 & Ommix I & $\begin{array}{l}\text { RV } \\
\text { UW }\end{array}$ & $\begin{array}{l}\text { Gyrodinium spp. } \\
\text { Gyrodinium spp. }\end{array}$ & $\begin{array}{l}13 \\
13\end{array}$ & $\begin{array}{l}1.7 \pm 0.58 \\
1.5 \pm 0.71\end{array}$ & $\begin{array}{l}0.10 \pm 0.03 \\
0.09 \pm 0.04\end{array}$ \\
\hline 16 Dec 2006 & Ommix II & $\begin{array}{l}\text { RV } \\
\text { UW }\end{array}$ & $\begin{array}{l}\text { Gyrodinium spp. } \\
\text { Gyrodinium spp. }\end{array}$ & $\begin{array}{l}13 \\
13\end{array}$ & $\begin{array}{l}1.5 \pm 0.58 \\
1.5 \pm 0.71\end{array}$ & $\begin{array}{l}0.09 \pm 0.03 \\
0.09 \pm 0.04\end{array}$ \\
\hline 11 Jun 2007 & Ommix III & $\begin{array}{l}\text { RV } \\
\text { UW }\end{array}$ & $\begin{array}{l}\text { Gymnodinium spp. } \\
\text { Gymnodinium spp. }\end{array}$ & $\begin{array}{l}11 \\
11\end{array}$ & $\begin{array}{l}1.4 \pm 1.0 \\
1.5 \pm 0.6\end{array}$ & $\begin{array}{l}0.08 \pm 0.06 \\
0.09 \pm 0.03\end{array}$ \\
\hline 13 Jun 2007 & Ommix IV & $\begin{array}{l}\text { RV } \\
\text { UW }\end{array}$ & $\begin{array}{l}\text { Gymnodinium spp. } \\
\text { Gymnodinium spp. }\end{array}$ & $\begin{array}{l}11 \\
11\end{array}$ & $\begin{array}{l}1.4 \pm 0.5 \\
2.0 \pm 0.9\end{array}$ & $\begin{array}{l}0.08 \pm 0.03 \\
0.12 \pm 0.05\end{array}$ \\
\hline 11 Dec 2007 & Ommix V & $\begin{array}{l}\text { UW } \\
\text { UW }\end{array}$ & $\begin{array}{l}\text { Gymnodinium spp. } \\
\text { Gyrodinium spp. }\end{array}$ & $\begin{array}{l}12.5 \\
12.5\end{array}$ & $\begin{array}{l}2.0 \pm 0.6 \\
1.25 \pm 0.5\end{array}$ & $\begin{array}{l}0.12 \pm 0.04 \\
0.07 \pm 0.03\end{array}$ \\
\hline 13 Dec 2007 & Ommix VI & $\begin{array}{l}\text { RV } \\
\text { RV } \\
\text { UW } \\
\text { UW }\end{array}$ & $\begin{array}{l}\text { Gymnodinium spp. } \\
\text { Gyrodinium spp. } \\
\text { Gymnodinium spp. } \\
\text { Gyrodinium spp. }\end{array}$ & $\begin{array}{l}12.5 \\
12.5 \\
12.5 \\
12.5\end{array}$ & $\begin{array}{l}2.1 \pm 0.7 \\
2.4 \pm 0.5 \\
1.6 \pm 0.7 \\
2.5 \pm 0.7\end{array}$ & $\begin{array}{l}0.12 \pm 0.04 \\
0.14 \pm 0.03 \\
0.09 \pm 0.04 \\
0.14 \pm 0.04\end{array}$ \\
\hline 9 Aug 2008 & Ommix VII & $\begin{array}{l}\text { RV } \\
\text { RV } \\
\text { UW } \\
\text { UW }\end{array}$ & $\begin{array}{l}\text { Gymnodinium spp. } \\
\text { Gyrodinium spp. } \\
\text { Gymnodinium spp. } \\
\text { Gyrodinium spp. }\end{array}$ & $\begin{array}{l}12 \\
12 \\
12 \\
12\end{array}$ & $\begin{array}{l}1.2 \pm 0.5 \\
1.4 \pm 0.5 \\
1.7 \pm 0.6 \\
1.0 \pm 0.1\end{array}$ & $\begin{array}{l}0.07 \pm 0.03 \\
0.08 \pm 0.03 \\
0.10 \pm 0.03 \\
0.06 \pm 0.01\end{array}$ \\
\hline Ciliates & & & & & & \\
\hline 11 Jun 2007 & Ommix III & $\begin{array}{l}\text { RV } \\
\text { UW }\end{array}$ & $\begin{array}{l}\text { Strombidium spp. } \\
\text { Strombidium spp. }\end{array}$ & $\begin{array}{l}11 \\
11\end{array}$ & $\begin{array}{l}2.0 \pm 0.0 \\
3.0 \pm 0.1\end{array}$ & $\begin{array}{l}19.90 \pm 1.20 \\
29.90 \pm 9.60\end{array}$ \\
\hline 13 Jun 2007 & Ommix IV & $\begin{array}{l}\text { RV } \\
\text { UW }\end{array}$ & $\begin{array}{l}\text { Strombidium spp. } \\
\text { Strombidium spp. }\end{array}$ & $\begin{array}{l}11 \\
11\end{array}$ & $\begin{array}{l}2.0 \pm 0.1 \\
2.3 \pm 1.2\end{array}$ & $\begin{array}{l}26.61 \pm 0.10 \\
31.05 \pm 15.36\end{array}$ \\
\hline 13 Dec 2007 & Ommix VI & $\begin{array}{l}\text { RV } \\
\text { UW }\end{array}$ & $\begin{array}{l}\text { Strombidium spp. } \\
\text { Strombidium spp. }\end{array}$ & $\begin{array}{l}12.5 \\
12.5\end{array}$ & $\begin{array}{l}3.0 \pm 0.1 \\
3.5 \pm 0.7\end{array}$ & $\begin{array}{l}29.94 \pm 1.10 \\
34.93 \pm 7.10\end{array}$ \\
\hline
\end{tabular}

Table 5. Clearance and ingestion rates by ciliates and dinoflagellates reported in the literature as determined using different techniques. $\mathrm{C}_{\max }$ : Maximum clearance rate reported, PNF: phototrophic nanoflagellates

\begin{tabular}{|c|c|c|c|c|}
\hline Predator & Technique & Prey & $\begin{array}{l}\text { Clearance rate } \\
\left(\mu l \text { pred. } .^{-1} \mathrm{~h}^{-1}\right)\end{array}$ & Source \\
\hline \multicolumn{5}{|l|}{ Dinoflagellates } \\
\hline Protoperidinium divergens & ${ }^{14} \mathrm{C}$ labelled natural food & $<10 \mu \mathrm{m}$ natural phytoplankton & $0.5-28$ & Lessard \& Swift (1985) \\
\hline Gyrodinium spirale & Food vacuole content & Dinoflagellate, Heterocapsa & $\mathrm{C}_{\max } 0.3$ & Hansen (1992) \\
\hline Gyrodinium galatheanum & Food vacuole content & Cryptophytes (PNF) & $0-0.27$ & Li et al. (2001) \\
\hline Gyrodinium dominans & Bottle incubation & Dinoflagellate, Prorocentrum & $\mathrm{C}_{\max } 0.9$ & Kim \& Jeong (2004) \\
\hline Gyrodinium spirale & Bottle incubation & Dinoflagellate, Prorocentrum & $\mathrm{C}_{\max } 5.3$ & Kim \& Jeong (2004) \\
\hline Protoperidinium bipes & Bottle incubation & Diatoms & $\sim 1$ & Jeong et al. (2004) \\
\hline Gyrodinium spp. & FLA disappearance & Isochrysis galbana & $2.5-5.8$ & Present study \\
\hline Gymnodinium spp. & FLA disappearance & I. galbana & $3.3-5.8$ & Present study \\
\hline \multicolumn{5}{|l|}{ Ciliates } \\
\hline $\begin{array}{l}\text { Different aloricate ciliate } \\
\text { species }\end{array}$ & ${ }^{14} \mathrm{C}$ labelled natural food & $<10 \mu \mathrm{m}$ natural phytoplankton & $0.7-213$ & Lessard \& Swift (1985) \\
\hline Strobilidium reticulatum & Particle uptake & $\begin{array}{l}\text { Pavlova lutheri } \\
\text { Tetraselmis suecica }\end{array}$ & $\begin{array}{l}2.6 \\
3.5\end{array}$ & Jonsson (1986) \\
\hline Ciliate populations & FLA disappearance & $\begin{array}{l}\text { Nannochloris } \\
\text { Chlorella }\end{array}$ & $\begin{array}{c}0.44-6.2 \\
1.2-8.3\end{array}$ & Sherr et al. (1991) \\
\hline $\begin{array}{l}\text { Strobilidium spiralis } \\
\text { Strombidium spp. }\end{array}$ & Food vacuole & Starch particles & $\begin{array}{c}11.4 \\
5.5-7.5\end{array}$ & Kivi \& Setälä (1995) \\
\hline Strombidinopsis sp. & Particle disappearance & Dinoflagellate, Scrippsiella trochoidea & $\mathrm{C}_{\max } 41$ & Jeong et al. (1999) \\
\hline Strombidium spp. & FLA disappearance & I. galbana & $0.8-1.5$ & Present study \\
\hline
\end{tabular}


carbon removal by naked dinoflagellates (Fig. 6a) was an order of magnitude lower than that by aloricate ciliates (Fig. 6b). Maximum carbon ingestion by naked dinoflagellates occurred during spring 2006 and 2007 , especially at Stn UW. In contrast, maximum carbon removal by aloricate ciliates occurred both on 13 June in winter at Stn RV and on 13 December in spring at Stn UW (Fig. 6b). In general, the highest carbon removal during spring by both naked dinoflagellates and ciliates was at Stn UW, suggesting a major top-down control of dinoflagellates on nanoflagellate carbon in this area.

\section{DISCUSSION}

\section{Ciliate and dinoflagellate occurrence}

Our estimates of ciliate and dinoflagellate abundance and biomass in this river-influenced continental shelf were within the lower range previously reported for this region. During the present study, we found abundances of up to 200 cells $\mathrm{ml}^{-1}$ for dinoflagellates and up to 20 cells $\mathrm{ml}^{-1}$ for ciliates (i.e. mostly aloricate cells). For the same study area, Böttjer \& Morales (2005) reported dinoflagellate abundances between 48 and 1286 cells $\mathrm{ml}^{-1}$ and ciliate abundances between 192 to 802 cells $\mathrm{ml}^{-1}$. Nevertheless, our results fit well with those reported recently by Anabalón et al. (2007). Based on a coastal time-series off Concepción, these authors reported the numerical dominance of species of the dinoflagellates Gyrodinium, Gymnodinium, and Protoperidinium, and the ciliates Strombidium, Strobilidium, and Helicostomella (tintinnid). They also reported maximum abundances of ciliates and dinoflagellates between fall and winter. Here, we also found low tintinnid abundances $\left(<1 \mathrm{cell} \mathrm{ml}^{-1}\right)$, as was also previously reported by Grünewald et al. (2001) for spring and winter months $\left(0.1\right.$ and 0.5 cells $\mathrm{ml}^{-1}$, respectively). Maximum abundances of dinoflagellates and tintinnids have been reported to be way offshore (Morales et al. 2007), which may explain our low abundances of tintinnids and oceanic dinoflagellate species such as Ceratium, Dissodinium, and Pyrocystis.

Our estimates of carbon biomasses are also consistent with values from the literature. Integrated dinoflagellate and ciliate biomasses in the upper $20 \mathrm{~m}$ reached maximum values of 1040 and $260 \mathrm{mg} \mathrm{C} \mathrm{m}^{-2}$, respectively. These values are well within the range of mean total protozoan biomass found in this and other coastal regions. Anabalón et al. (2007) reported integrated (0 to $30 \mathrm{~m}$ ) biomasses ranging from 150 to 3090 and 70 to $230 \mathrm{mg} \mathrm{C} \mathrm{m}^{-2}$ for dinoflagellates and ciliates, respectively. Similarly, Vargas et al. (2007) in a seasonal carbon flow study in the same study area, found

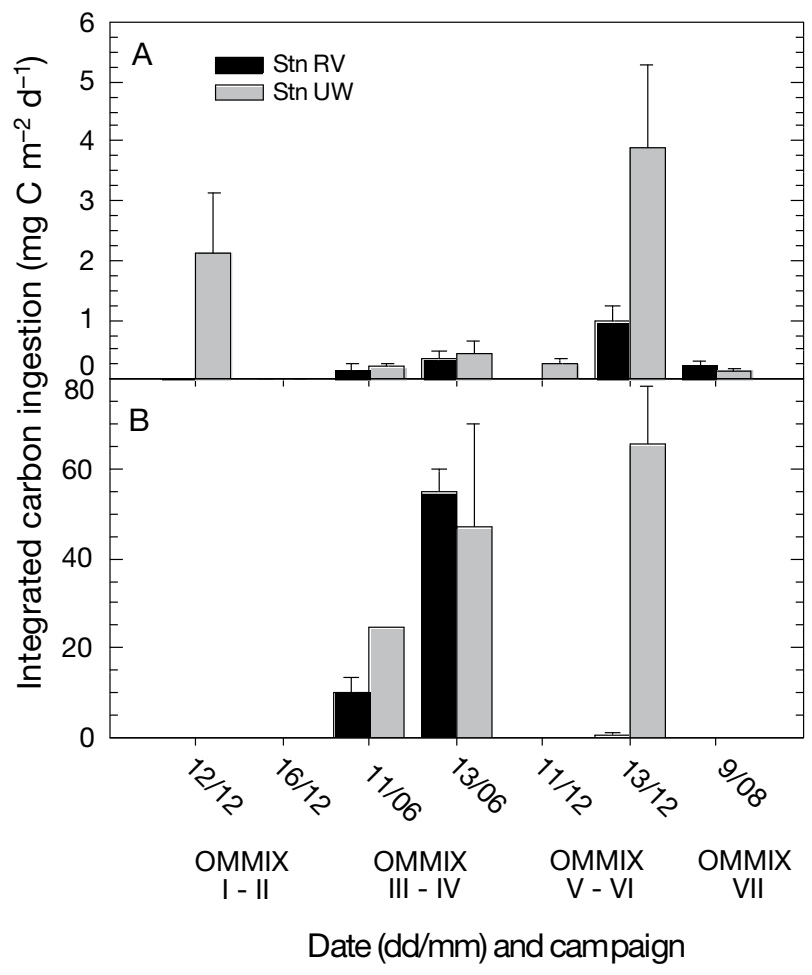

Fig. 6. Integrated carbon ingestion $\left(\mathrm{mg} \mathrm{C} \mathrm{m}^{-2} \mathrm{~d}^{-1}\right)$ (means \pm $\mathrm{SD}$ ) of (A) naked dinoflagellates, and (B) aloricate ciliates in the upper $20 \mathrm{~m}$ of both Stns RV and UW during each sampling campaign

that ciliate and dinoflagellate biomasses ranged from 1 to 1300 and 200 to $2500 \mathrm{mg} \mathrm{C} \mathrm{m}^{-2}$, respectively. Maar et al. (2002) reported respective biomasses of up to 109 and $171 \mathrm{mg} \mathrm{C} \mathrm{m}^{-2}$ for ciliates and dinoflagellates in a temperate coastal ecosystem at Skagerrak.

The present study, although limited in terms of spatial coverage, revealed the high mesoscale spatial heterogeneity between 2 sampling sites influenced by different oceanographic processes (i.e. river runoff and coastal upwelling). Our results showed the influence of the freshwater discharge from the Itata river in modifying the physical structure of the water column through changes in salinity and density, but also in providing a terrigenous flux of $\mathrm{Si}(\mathrm{OH})_{4}$, which increased $\mathrm{Si}$ :N ratios in the surface layer at this site. Nevertheless, the upward injection of $\mathrm{NO}_{3}^{-}$and $\mathrm{Si}(\mathrm{OH})_{4}$ by upwelling pulses occurring near Coliumo Bay (Stn UW) is also a major source of enhanced nutrients supporting the typical large diatom blooms at this site (Vargas et al. 2006a, 2007). Consequently, this interplay among the strong signals in freshwater runoff, solar radiation, and wind-driven upwelling may exert a significant influence on physical stratification and chemical properties (i.e. flux of essential nutrients and organic matter), which dramatically influence plankton community structure in these river-influenced continental shelf 
waters. In fact, we found a significant association between dinoflagellate abundance and the river plume environment (Stn RV), as indicated by the significant correlation between armoured dinoflagellate abundance and PC3 ('river flow component') (Table 3b). PC3 showed a negative weight for river flow and a positive weight for salinity; thus, the negative correlation between PC3 and armoured dinoflagellate abundance suggests the latter's association with enhanced freshwater runoff (Table 3). In fact, a significant peak in the biomass of armoured dinoflagellates occurred during a maximum stratification period at the river plume area (Fig. 5a). The association between freshwater plumes and dinoflagellates has been observed in several coastal areas worldwide (e.g. Hallegraeff et al. 1995). It is unclear whether this relationship is principally caused by the direct effects of nutrients, dissolved organic matter that might serve as growth stimulants, or increased water column stability. Humic substances supplied in freshwater runoff from the heavily forested Itata watershed may play a role in enhancing dinoflagellate abundances, as humics have been shown to have a positive effect on the growth of several dinoflagellate species. Carlsson et al. (1995) observed that humic substances from river discharge might enhance the abundance of oligotrichous ciliates in river mouths due to an increase in bacterial production. In fact, estimations of bacterial production during the present Ommix campaigns showed permanently higher bacterial production rates in the river plume at Stn RV than at Stn UW (C.A. Vargas unpubl. data). Therefore, we can assume that DOM increases caused by increases in river runoff may provide an extra source of carbon for bacterial growth. Aloricate ciliates were positively correlated with PC1 and PC2, which are respectively associated with nutrient conditions and upwelling variability. Although ciliates were more abundant during winter months in the river plume area, their maximum abundance (i.e. mostly dominated by Strombidium sp.) at Stn UW was associated with the fluorescence maximum depth during upwelling conditions in spring 2007. Nevertheless, the relatively similar percentages of the total variance that is explained by each principal component (i.e. 27.5, 22.4, and $18.5 \%$ for PC1, PC2, and $\mathrm{PC} 3$, respectively), suggest that environmental variability is driven by multiple factors acting in relatively similar proportions (e.g. nutrients, upwelling, and river runoff).

\section{Feeding behaviour}

Most of the small aloricate ciliates can ingest freeliving bacteria (e.g. Neuer \& Cowles 1995). However, turnover rates of bacteria due to grazing by ciliates are usually lower than those due to grazing by heterotrophic nanoflagellates (Ichinotsuka et al. 2006). Large aloricate ciliates between 30 and $50 \mu \mathrm{m}$, such as those found in our present study (i.e. mostly Strombidium spp. and Strobilidium spp.), are likely consumers of 3 to $5 \mu \mathrm{m}$ nanoplankton-sized algae (Bernard \& Rassoulzadegan 1990). In fact, results from our FLA uptake experiments indicate that ingestion by the aloricate ciliates Strombidium spp. ( 20 to 35 prey d $^{-1}$ ) can be an order of magnitude higher than that by the naked dinoflagellates Gymnodinium spp. and Gyrodinium spp. (0.06 to 0.14 prey $\left.\mathrm{d}^{-1}\right)$. Our estimates were within the range of those reported in different studies (e.g. see Table 5), which show the feasibility of the FLA method used. For instance, Li et al. (2001) estimated clearance values by Gyrodinium galatheanum of up to $0.27 \mu \mathrm{l}$ ind..$^{-1} \mathrm{~h}^{-1}$, using a similar methodological approach, and Hansen (1992) reported clearance rates of $0.3 \mu \mathrm{l}$ ind..$^{-1} \mathrm{~h}^{-1}$ in field populations of Gyrodinium spirale, using food vacuole content analysis. Estimations using other methods have resulted in different ranges of clearance rates, which were still within the range found in our study. Rates reported from cell removal in bottle incubation experiments reached values of up to 0.9 and $5.3 \mu \mathrm{lind} .^{-1} \mathrm{~h}^{-1}$ for Gyrodinium dominans and G. spirale, respectively (Kim \& Jeong 2004). For ciliate species, Jonsson (1986) estimated clearance rates of 2.6 and $3.5 \mu \mathrm{lind} .^{-1} \mathrm{~h}^{-1}$ for Strobilidium reticulatum feeding on the flagellates Pavlova lutheri and Tetraselmis suecica, respectively. Using food vacuole content with starch particles as a tracerlevel food source, Kivi \& Setälä (1995) estimated clearance rates of 11.4 and $\sim 6.5 \mu \mathrm{l}$ ind. ${ }^{-1} \mathrm{~h}^{-1}$ for Strobilidium spiralis and Strombidium spp, respectively. However, caution should be exercised in these kinds of experiments due to potential biases, including: (1) differential uptake of live compared to dead prey cells (Stoecker 1988), (2) differential FLA uptake when using different algae (Sherr et al. 1991), and (3) the lack of an adequate number of experiments to determine the $k$ parameter. A comparison of clearance rates on different kinds of FLA, and on live vs. dead phytoplankton remains to be done. However, we believe that our clearance and ingestion rate data constitute reliable values for first estimations of the potential grazing impact in this area.

\section{Implications for ecosystem functioning in river- influenced coastal areas}

Measurements of integrated (upper $20 \mathrm{~m}$ depth) size-fractioned PP made during each sampling campaign (J. L. Iriarte unpubl. data) showed contrasting nanoplankton PP (nano-PP) values between spring and 


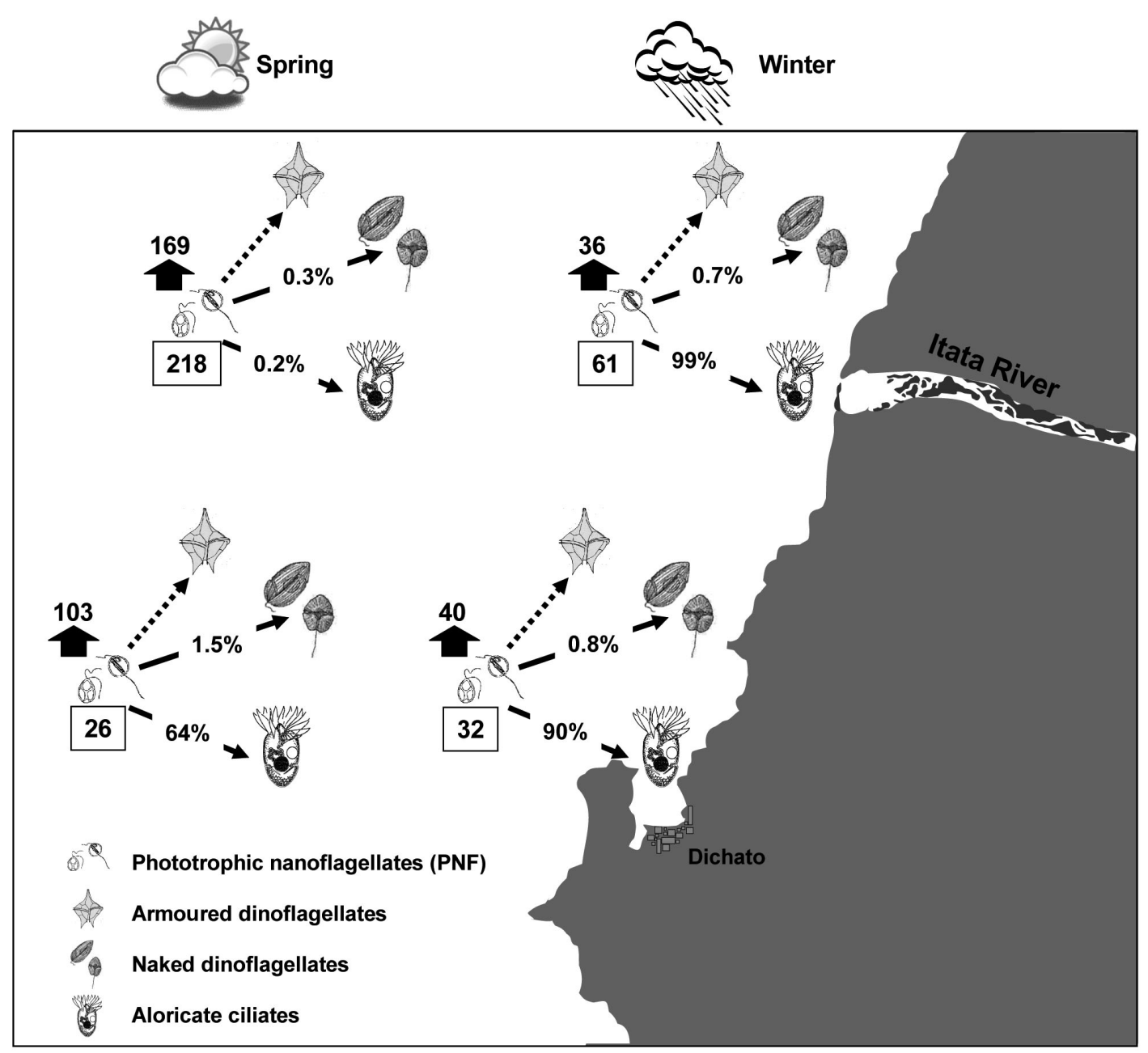

Fig. 7. Carbon fluxes between nanophytoplankton $(2-20 \mu \mathrm{m})$ and microzooplankton (ciliates and dinoflagellates) averaged for spring and winter seasons, for the Itata River plume area (Stn RV) and off Coliumo Bay (Stn UW). Numbers inside boxes show the integrated biomass of phototrophic nanoflagellates $\left(\mathrm{mg} \mathrm{C} \mathrm{m}^{-2}\right)$; numbers above wide arrows show nanophytoplankton primary production (nano-PP, mg C m ${ }^{-2} \mathrm{~d}^{-1}$ ). The percentages on thin continuous arrows represent the \% of nano-PP consumed $\mathrm{d}^{-1}$; dashed arrows represent potential trophic links between armoured dinoflagellates and nanoflagellates, which was not evaluated in the present study

winter campaigns: high values (103 to $169 \mathrm{mg} \mathrm{C} \mathrm{m}{ }^{-2}$ $\mathrm{d}^{-1}$ ) were noted during spring and low values (36 to $40 \mathrm{mg} \mathrm{C} \mathrm{m}{ }^{-2} \mathrm{~d}^{-1}$ ) were observed during winter, with insignificant differences between sampling stations. Using these data and our estimates of ingestion rates, we calculated the carbon consumption of aloricate ciliate and naked dinoflagellate populations (Fig. 6), as well as their grazing impact on nano-PP (see Fig. 7).

Carbon ingestion by naked dinoflagellates ranged from 0.1 to $\sim 5 \mathrm{mg} \mathrm{C} \mathrm{m}^{-2} \mathrm{~d}^{-1}$, whereas aloricate ciliates removed between 0 and $\sim 70 \mathrm{mg} \mathrm{C} \mathrm{m}^{-2} \mathrm{~d}^{-1}$, with maximum carbon ingestion for both groups occurring during spring and winter months. These values result in a higher grazing impact of aloricate ciliates $(0.2$ to $99 \%$ of nano-PP d $\mathrm{d}^{-1}$ ) than of naked dinoflagellates (0.3 to
$1.5 \%$ of nano-PP $\mathrm{d}^{-1}$ ). The highest grazing impact of ciliates on nano-PP occurred during winter months, especially in the river plume Stn RV (99\% of nano-PP $\mathrm{d}^{-1}$ ) (Fig. 7). The grazing impact of ciliates in the river plume was relatively low during spring, which is mostly due to their low abundance at this time. Thus, PNF abundance at Stn RV was not controlled by ingestion by these micrograzers, as indicated by higher PNF biomass at Stn RV than at Stn UW. Although carbon ingestion from armoured dinoflagellates was not considered in these estimations, they may, at times, significantly contribute to phytoplankton grazing. However, with few exceptions, Protoperidinium species (the dominant armoured dinoflagellates in the present study) have been observed to feed only on diatoms, 
and small nanoflagellates may generally be unable to support Protoperidinium growth (Naustvoll 2000). Nevertheless, the potential impact of other microphage feeders, such as copepod nauplii (Smith et al. 2008) and invertebrate larvae (Vargas et al. 2006b), on nanoplankton should be considered.

Based on our results, the total grazing impact of aloricate ciliates and naked dinoflagellates could reach up to $100 \%$ of nano-PP d $\mathrm{d}^{-1}$. Studies on the importance of microzooplankton grazing on PP in coastal areas off Chile have been largely derived from investigations employing model-derived estimations (Vargas \& González 2004), the size-fractionation method (Vargas et al. 2007, 2008), and the seawater dilution technique (Böttjer \& Morales 2005). These studies commonly resulted in high levels of grazing impact on nano-PP. For instance, Vargas et al. (2007) estimated a potential microzooplankton grazing impact of between 14 and $36 \%$ of nano-PP $\mathrm{d}^{-1}$. Böttjer \& Morales (2005) concluded that microzooplankton grazing during winter can be high, especially on the nanoplankton fraction, and they estimated a potential impact of microzooplankton on nano-PP of 132 to $185 \% \mathrm{~d}^{-1}$. However, Dolan \& McKeon (2004) have recently provided evidence that high grazing rates derived from dilution experiments could be an artefact due to overestimation, and they argued that grazing should probably not exceed $50 \%$ of $\mathrm{PP} \mathrm{d}^{-1}$, or could even be lower in coastal areas. Furthermore, it is clear from our results that the large difference in grazing rates between ciliates and dinoflagellates suggests that grazing rate estimates from dilution and size fractionation methods should be reconsidered. This is mostly because the total grazing pressure by microzooplankton should result from a complex combination of the different feeding responses of various predators to nanoplankton prey (Sherr et al. 1991). Whatever the method, our findings demonstrate that organisms from the microbial food web, such as ciliates and dinoflagellates, may control the nanoplankton assemblage and thus represent an important trophic intermediary between the classical and microbial food webs in this coastal ecosystem.

Protozoans may play an important role as grazers of phytoplankton in river plume areas (Dagg et al. 2004). For instance, Fahnenstiel et al. (1995) studied microzooplankton grazing in river plumes of the Gulf of Mexico, and reported that microzooplankton grazing rates on cells $<20 \mu \mathrm{m}$ averaged $82 \%$ of algal growth rates in the river plume region. Furthermore, mixotrophic ciliates and dinoflagellates in stratified waters can exploit nutrient-rich waters below the pycnocline as well as light in the euphotic zone, which confers an advantage over nonmotile microphytoplankton. These findings have important implications on the potential effects of natural (climate change) and/or anthro- pogenic factors (e.g. dam construction and other watershed uses) in modifying river flow to the coastal ocean, and altering physical/chemical conditions and microbial food web dynamics in river-influenced continental shelf waters.

Acknowledgements. We thank the captains and crew of the research vessel LC 'Kay-Kay' and the Ommix team who participated in our cruises (especially P. Contreras, R. Bermúdez, C. Valenzuela, and D. Opazo); J. L. Iriarte for providing primary production data and R. Escribano (COPAS Center) for providing the PAR data; R. Escribano for providing all the logistic facilities at the Marine Research Station of Dichato and onboard the RV 'Kay-Kay', Universidad de Concepción; and F. Tapia (COPAS Center) for all the statistical advice. We also thank the responsible editor and 2 anonymous referees for their helpful suggestions that substantially improved this paper. Financial support for this study was fully provided by the FONDECYT Project No. 1060709 to C.A.V.

\section{LITERATURE CITED}

Anabalón V, Morales CE, Escribano R, Varas MA (2007) The contribution of nano- and microplanktonic assemblages in the surface layer $(0-30 \mathrm{~m})$ under different hydrographic conditions in the upwelling area off Concepción, central Chile. Prog Oceanogr 75:396-414

Bernard C, Rassoulzadegan F (1990) Bacteria or microflagellates as a major food source for marine ciliates: possible implications for the microzooplankton. Mar Ecol Prog Ser 64:147-155

Böttjer D, Morales CA (2005) Microzooplankton grazing in a coastal embayment off Concepción, Chile, $\left(\sim 36^{\circ} \mathrm{S}\right)$ during non-upwelling conditions. J Plankton Res 27: 383-391

Calbet A (2008) The trophic roles of microzooplankton in marine systems. ICES J Mar Sci 65:325-331

Carlsson P, Graneli E, Tester P, Boni L (1995) Influences of riverine humic substances on bacteria, protozoa, phytoplankton, and copepods in a coastal plankton community. Mar Ecol Prog Ser 127:213-221

Christaki U, Jacquet S, Dolan JR, Vaulot D, Rassoulzadegan F (1999) Growth and grazing on Prochlorococcus and Synechococcus by two marine ciliates. Limnol Oceanogr 44: $52-61$

> Dagg M, Benner R, Lohrenz S, Lawrence D (2004) Transformation of dissolved and particulate materials on continental shelves by large rivers: plume processes. Cont Shelf Res 24:833-858

Dolan JR, McKeon K (2004) The reliability of grazing rate estimates from dilution experiments: Have we overestimated rates of organic carbon consumption? Ocean Sci Discuss 1: 21-36

Dolan JR, Šimek K (1997) Processing of ingested matter in Strombidium sulcatum, a marine ciliate. Limnol Oceanogr 42:393-397

> Fahnenstiel GL, McCormick MJ, Lang GA, Redalje DG and others (1995) Taxon-specific growth and loss rates for dominant phytoplankton populations from the northern Gulf of Mexico. Mar Ecol Prog Ser 117:229-239

Gifford DJ, Caron DA (2000) Sampling, preservation, enumeration and biomass of marine protozooplankton. In: Harris RP, Wiebe PH, Lenz J, Skjoldal HR, Huntley M (eds) ICES zooplankton methodology manual. Academic Press, San Diego, CA, p $193-221$ 
Grünewald AC, Morales CE, González HE, Sylvester C, Castro LR (2002) Grazing impact of copepod assemblages and gravitational flux in coastal and oceanic waters off central Chile during two contrasting seasons. J Plankton Res 24: $55-67$

Haas LW (1982) Improved epifluorescence microscopy for observing planktonic microorganisms. Ann Inst Oceanogr 58:261-266

Hallegraeff GM, McCausland MA, Brown RK (1995) Early warning of toxic dinoflagellate blooms of Gymnodinium catenatum in southern Tasmanian waters. J Plankton Res 17:1163-1176

Hansen PJ (1992) Prey size selection, feeding rates and growth dynamics of heterotrophic dinoflagellates with special emphasis on Gyrodinium spirale. Mar Biol 114: 327-334

Hansen B (1993) Aspects of feeding, growth and stage development by trochophora larvae of the boreal polychaete Mediomastus fragile (Rasmussen) (Capitellidae). J Exp Mar Biol Ecol 166:273-288

> Ichinotsuka D, Ueno H, Nakano SI (2006) Relative importance of nanoflagellates and ciliates as consumers of bacteria in a coastal sea area dominated by oligotrichous Strombidium and Strobilidium. Aquat Microb Ecol 42:139-147

Jeong HJ, Shim JH, Lee CW, Kim JS, Koh SM (1999) Growth and grazing rates of the marine planktonic ciliate Strombidinopsis sp. on red-tide and toxic dinoflagellates. J Eukaryot Microbiol 46:69-76

> Jeong HJ, Yoo YD, Kim ST, Kang NS (2004) Feeding by the heterotrophic dinoflagellate Protoperidinium bipes on the diatom Skeletonema costatum. Aquat Microb Ecol 36: 171-179

Jonsson PR (1986) Particle size selection, feeding rates and growth dynamics of marine planktonic oligotrichous ciliates (Ciliophora: Oligotrichina). Mar Ecol Prog Ser 33: 265-277

Kim JS, Jeong HJ (2004) Feeding by the heterotrophic dinoflagellates Gyrodinium dominans and G. spirale on the red-tide dinoflagellate Prorocentrum minimum. Mar Ecol Prog Ser 280:85-94

Kivi K, Setälä O (1995) Simultaneous measurement of food particle selection and clearance rates of planktonic oligotrich ciliates (Ciliophora: Oligotrichina). Mar Ecol Prog Ser 119:125-137

Lessard EJ, Swift E (1985) Species-specific grazing rates of heterotrophic dinoflagellates in oceanic waters, measured with a dual-label radioisotope technique. Mar Biol 87: 289-296

Levinsen H, Nielsen TG (2002) The trophic role of marine pelagic ciliates and heterotrophic dinoflagellates in Arctic and temperate coastal ecosystems: a cross latitude comparison. Limnol Oceanogr 47:427-436

Li A, Stoecker DK, Coats DW (2001) Use of the 'food vacuole content' method to estimate grazing by the mixotrophic dinoflagellate Gyrodinium galatheanum on chryptophytes. J Plankton Res 23:303-318

Maar M, Nielsen TG, Richardson K, Christaki U, Hansen OS, Zervoudaki S, Christou ED (2002) Spatial and temporal variability of food web structure during the spring bloom in the Skagerrak. Mar Ecol Prog Ser 239:11-29

> Montero P, Daneri G, Cuevas LA, González HE, Jacob B, Lizárraga L, Menschel E (2007) Productivity cycles in the coastal upwelling area off Concepción: the importance of diatoms and bacterioplankton in the organic carbon flux. Prog Oceanogr 75:518-530

Morales CE, González HE, Hormazabal SE, Yuras G, Letelier
J, Castro LR (2007) The distribution of chlorophyll $a$ and dominant planktonic components in the coastal transition zone off Concepción, central Chile, during different oceanographic conditions. Prog Oceanogr 75:452-469

Naustvoll LJ (2000) Prey size spectra and food preferences in thecate heterotrophic dinoflagellates. Phycologia 39: $187-198$

- Neuer S, Cowles TJ (1995) Comparative size-specific grazing rates in field populations of ciliates and dinoflagellates. Mar Ecol Prog Ser 125:259-267

Ohman MD, Snyder RA (1991) Growth kinetics of the omnivorous oligotrich ciliate Strombidium sp. Limnol Oceanogr 36:922-935

> Pomeroy LR (1974) The ocean's food web: a changing paradigm. Bioscience 24:499-504

Rassoulzadegan F, Laval-Peuto M, Sheldon RW (1988) Partitioning of the food ration of marine ciliates between picoand nanoplankton. Hydrobiologia 159:75-88

Rublee PA, Gallegos ChL (1989) Use of fluorescently labelled algae (FLA) to estimate microzooplankton grazing. Mar Ecol Prog Ser 51:221-227

- Sánchez GE, Pantoja S, Lange CB, González HE, Daneri G (2008) Seasonal changes in particulate biogenic and lithogenic silica in the upwelling system off Concepción $\left(\sim 36^{\circ} \mathrm{S}\right)$, Chile, and their relationship to fluctuations in marine productivity and continental input. Cont Shelf Res 28:2594-2600

Sherr EB, Sherr BF (1993) Protistan grazing rates via uptake of fluorescently labelled prey. In: Kemp PF, Sherr BF, Sherr EB, Cole JJ (eds) Handbook of methods in aquatic microbial ecology. Lewis Publishers, Boca Raton, FL, p 685-701

Sherr EB, Sherr BF (2007) Heterotrophic dinoflagellates: a significant component of microzooplankton biomass and major grazers of diatoms in the sea. Mar Ecol Prog Ser 352: $187-197$

Sherr BF, Sherr EB, Fallon RD (1987) Use of monodispersed, fluorescently labelled bacteria to estimate in situ protozoan bacterivory. Appl Environ Microbiol 53:958-965

Sherr EB, Sherr BF, McDaniel J (1991) Clearance rates of <6 $\mu \mathrm{m}$ fluorescently labelled algae (FLA) by estuarine protozoa: potential grazing impact of flagellates and ciliates. Mar Ecol Prog Ser 69:81-92

Smith JK, Lonsdale DJ, Gobler CJ, Caron DA (2008) Feeding behavior and development of Acartia tonsa nauplii on the brown tide alga Aerococcus anophagefferens. J Plankton Res 30:937-950

Stoecker DK (1988) Are marine planktonic ciliates suspension feeders? J Protozool 35:252-255

Strickland JDH, Parsons TR (1968) Determination of reactive nitrite. In: A practical handbook of seawater analysis. Bull Fish Res Board Can 167:71-75

- Tiselius P (1989) Contribution of aloricate ciliates to the diet of Acartia clausi and Centropages hamatus in coastal waters. Mar Ecol Prog Ser 56:49-56

- Vargas CA, González HE (2004) Plankton community structure and carbon cycling in a coastal upwelling system. II. Microheterotrophic pathway. Aquat Microb Ecol 34: 165-180

Vargas CA, Escribano R, Poulet S (2006a) Phytoplankton diversity determines time-windows for successful zooplankton reproductive pulses. Ecology 87:2992-2999

Vargas CA, Manríquez P, Navarrete SA (2006b) Feeding by larvae of intertidal invertebrates: assessing their position in pelagic trophic webs. Ecology 87:444-457

Vargas CA, Martínez R, Cuevas LA, Pavez M and others (2007) The relative importance of microbial and classical 
food webs in a highly productive coastal upwelling area. Limnol Oceanogr 52:1495-1510

Vargas CA, Martínez RA, González HE, Silva N (2008) Contrasting trophic interactions of microbial and copepod communities in a fjord ecosystem, Chilean Patagonia.

Editorial responsibility: Robert Sanders,

Philadelphia, Pennsylvania, USA
Aquat Microb Ecol 53:227-242

> Weise AM, Levasseur M, Saucier FJ, Senneville S and others (2002) The link between precipitation, river runoff, and blooms of the toxic dinoflagellate Alexandrium tamarense in the St. Lawrence. Can J Fish Aquat Sci 59:464-473

Submitted: November 19, 2008; Accepted: May 6, 2009 Proofs received from author(s): July 8, 2009 